\title{
Effects of Customer Service Strategies on Customer Satisfaction of Firms in the Telecommunication Sector in Kenya
}

\author{
Ng'ang'a Ruth Wanjiku' ${ }^{1}$ Dr. Kepha Ombui ${ }^{2}$, Dr. Mike Iravo ${ }^{3}$ \\ MBA: Jomo Kenyatta University of Agriculture and Technology
}

\begin{abstract}
The main aim of the study was to examine the effects of customer service strategies on customer satisfaction of firms in the Telecommunication sector. In order to capture the required information, the study was guided by four specific objectives; to determine the effect of service quality strategies on customer satisfaction of firms in the telecommunication sector; to establish the extent to which pricing strategies influence customer satisfaction of firms in the telecommunication sector; to assess the effect of brand image strategies on customer satisfaction of firms in the telecommunication sector and to determine the effects of service recovery strategies on customer satisfaction of firms in the telecommunication sector. The study reviewed several theories of satisfaction as possible avenues towards a framework of understanding what satisfies customers. The study also conducted an empirical literature review in order to establish a link with similar past studies. The study adopted a descriptive survey design utilizing both primary and secondary data. Structured and unstructured questionnaires were used to collect primary data which were administered as the customers queued in the customer service centers while secondary data was collected through document review. Data analysis was carried out using qualitative and quantitative techniques with the aid of SPSS while the main method of data presentation was frequency distribution, tables, pie charts and bar graphs. The study found that there is a significant relationship between customer service strategies and customer satisfaction. The study concluded that customer service played a big role in influencing customer satisfaction and given a choice customers showed preference for fair and justified pricing, better quality of services, prompt and effective service recovery and were more likely to subscribe to a service provider with a good brand image. The study recommends that management of telecommunication firms should ensure proper and fair pricing, avoid unfavorable price alterations and anticipate customer's potential feelings on price. On service quality, management should deliver quality, reliable and uninterrupted services. Management should focus on quick service recovery and communicate promptly on forthcoming interruptions. Telecommunication managers must also make a concerted effort to develop a distinct brand image or brand identity that resonates with customers but also clearly distinguishes that brand from its competitors to ensure satisfaction. Finally the research study recommends that a future study similar to this should be carried out in other areas and counties in Kenya and findings be compared to help telecommunication managers and other managers in the service industry find concrete solutions to poor customer satisfaction in Kenya.
\end{abstract}

Keywords: customer satisfaction, pricing, service quality, service recovery, brand image

\section{Introduction}

To gain competitive advantage in a fast changing environment, firms must continuously adjust their business strategies to fit that environment. One important strategy is to maintain good customer relationships through customer satisfaction (Gwinner et al.., 2008; Storbacka et al., 2004). A good way to ensure customer satisfaction is to provide what customers really need and want. But customers ${ }^{\text {ee }}$ needs and wants change over time. For a service firm, it is critical to cope with this problem. Satisfaction reveals a person's comparative judgements resulting from a product ${ }^{\text {te }}$ perceived performance (or outcome) in relation to his or her expectations. If the performance falls short of expectations, the customer is dissatisfied and disappointed. If the performance matches the expectations, the customer is satisfied. If the performance exceeds expectations, the customer is highly satisfied or delighted (Kotler, 2006). Keeping current customers satisfied is just as important as attracting new ones and a lot less expensive (Lamb, 2000).

Customer satisfaction holds the potential for increasing an organization's customer base, increasing the use of more volatile customer mix and increasing the firm"s reputation (Fornell. 2002, Levesque and McDaugall. 2011). One path to achieving customer satisfaction is through customer service. Customer service is the provision of service to customers, before, during and after a purchase. Zeithami and Bitner (2003) defined customer service as a series of activities designed to enhance the level of customer's satisfaction that is, the feeling that a product or service has met customer"s expectation. Customer service varies by product, sector and customer. It however assumes an important dimension in service delivery and sales of product. This is because service firms such as Telecommunication firms, have no inventory of finished goods to buffer production from random demand variability. Nevertheless, it is demanded that for corporation "es survival, profitability and growth that service firms hold their own in competition.

The Nigerian telecommunication sector for one, has witnessed significant rise in competition in recent years due largely to the deregulation policy of government and the advent of mobile telecommunication companies. Another complex dimension to the competitive trend in the Nigerian telecommunication sector is the ease and rate at which products and services are duplicated in the sector and the multi dimension nature of communication. This trend fosters a scenario of continuous fight for customer share (Mendzela, 2009) and, an increasing need to build loyal customers through effective customer"s service activities. Loyal customers, from cost perspective tend to stay longer with the preferred providers, buy more and generate favorable wordof-mouth effect that may further benefit the preferred 


\section{International Journal of Science and Research (IJSR) \\ ISSN (Online): 2319-7064 \\ Index Copernicus Value (2013): 6.14 | Impact Factor (2015): 6.391}

provider. (Reicheld and Kenny, 2010). Further, long term customers tend to take less of company time and are, somehow less sensitive to price (Gan et al., 2006). Gan et al. (2006), further indicates that retaining customers becomes a priority for most enterprises and there are compelling arguments for managers to carefully consider the factors that might increase customer's retention rate. In any case, the cost of creating a new customer has been estimated to be five times the cost of retaining an existing customer (Reichheld, 2005).

The telecommunications sector in Kenya provides communication and information services, i.e. delivery of voice, data and media over different networks, including computer networks, mobile and telephone networks, and television networks. A currently dominant view is to divide the telecommunication companies ${ }^{\text {ee }}$ day-to-day operations in to vertical processes of service fulfillment, service assurance and billing (Kelly, 2003; TMF, 2005). Further, the view seeks to divide the processes according to the horizontal layers of customer management, service management and network management.

The specific objectives of the study were;

1) To determine the effect of pricing strategies on customer satisfaction of firms in the telecommunication sector.

2) To determine the effect of service quality strategies on customer satisfaction of firms in the telecommunication sector.

3) To determine the effect of service recovery strategies on customer satisfaction of firms in the telecommunication sector.

4) To determine the effect of brand image strategies on customer satisfaction of firms in the telecommunication sector.

\section{Theoretical Review}

\subsection{Assimilation Theory}

Kurt Lewin originally formulated the theory of cognitive dissonance, which was later developed and refined by Festinger (1957). The dissonance theory forms the basis of the assimilation theory. The dissonance theory posits that the users of a particular product make some kind of cognitive comparison between expectations about the product and the perceived product performance. If there is a discrepancy between expectations and perceived product performance then dissonance or negative disconfirmation arises. This view of the consumer "post-usage evaluation" was introduced into the satisfaction literature in the form of assimilation theory by Anderson, in his work on consumer dissatisfaction; the effect of disconfirmed expectancy on perceived product performance. According to Anderson, consumers seek to avoid dissatisfaction by "adjusting perceptions about a given product to bring it more in line with expectations". Consumers can also reduce the dissatisfaction resulting from a discrepancy between expectations and product performance either by altering expectations so that they coincide with perceived product performance or by raising the level of satisfaction by minimizing the relative importance of the dissatisfaction experienced (Olson \& Dover, 1979).
However, the assimilation theory has a number of weaknesses. First, the approach postulates that there is a relationship between expectation and satisfaction but does not specify how disconfirmation of an expectation leads to either satisfaction or dissatisfaction. Next, the theory also postulates that consumers are inspired enough to adjust either their expectations or their perceptions about the performance of the product (Forman, 1986). According to Peyton et al, "if the consumer adjusts either expectations or perceptions about product performance then dissatisfaction would not be an outcome of the post-usage evaluation process". A number of scholars such as Olson and Dover and Anderson have found that controlling for actual product performance can lead to a positive relationship between expectation and satisfaction. Therefore, Bitner argues that it would seem that dissatisfaction could never occur except the evaluative processes were to begin with negative consumeres expectations.

\subsection{Contrast Theory}

The Contrast theory was first introduced by Hovland, Harvey and Sherif (1987). Dawes et al (1972) defines contrast theory as the tendency to magnify the discrepancy between one s own attitudes and the attitudes represented by opinion statements. However, Cardozo claims that the theory presents an alternative view of the consumer "post-usage evaluation process" in contrast to the assimilation theory that hypothesized that post-usage evaluation leads to outcomes in opposite predictions for the effects of expectations on satisfaction. The contrast theory posits that consumers would exaggerate any contrast between expectation and product evaluation. Dawes, Singer and Lemons (1999) define contrast theory as the propensity to magnify the discrepancy between "one's own attitudes and the attitudes represented by opinion statements"/validated by persons with opposing views. Whereas assimilation theory suggests that users will seek to minimize the discrepancy between expectation and performance; contrast theory argues that a surprise effect arises leading to the discrepancy being exaggerated. . If the firm raises expectations in his advertising, and then a customer's experience is only slightly less than that promised, the product/service would be rejected as totally un-satisfactory. Conversely, under-promising in advertising and over-delivering will cause positive disconfirmation also to be exaggerated. This theory was further developed into the assimilation-contrast theory by Anderson.

\subsection{Assimilation-Contrast Theory}

The assimilation-contrast model has been proposed as yet another way to explain the relationships among the variables in the disconfirmation mode. This model is a combination of both the assimilation and the contrast theories; the model postulates that satisfaction is a function of the magnitude of the discrepancy between expected and perceived performance. Generally, consumers of any product have "zones or latitudes of acceptance or rejection with respect to their perceptions". As with assimilation theory, the user will tend to adjust differences in perceptions about product performance to bring it in line with prior expectations, but only if the discrepancy is relatively small. Peyton et al. noted that when there is a "large discrepancy between expectations 


\section{International Journal of Science and Research (IJSR) \\ ISSN (Online): 2319-7064 \\ Index Copernicus Value (2013): 6.14 | Impact Factor (2015): 6.391}

and perceived performance, contrast effects occur and the consumer tends to magnify the perceived difference". However, it should be noted that most discrepancies with a given product are not just magnified or exaggerated, but they are simply the true evaluation of the product, based on what the consumers ${ }^{\text {ec }}$ have experienced. Some evaluation can be an emotional expression of the user judgment with regards to the functionality of the product. On the other hand, Peyton et al posits that whether assimilation or contrast occurs depends upon the perceived disparity between expectations and actual product performance.

The assimilation-contrast theory also argues that Cardozo es attempt in the assimilation theory at reconciling the two earlier theories was methodologically weak; Anderson presented his adaptation of an earlier work. He asserted that consumers possess a "noticeable difference disconfirmation threshold". Assimilation-contrast theory attempt demonstrate that both the assimilation and the contrast theory models have applicability in the study of consumer satisfaction. The approach makes it possible to "... hypothesize variables other than the magnitude of the discrepancy that might also influence whether the assimilation effect or the contrast effect would be observed... when product performance is difficult to judge, expectations may dominate and assimilation effects would be observed... contrast effects would result in high involvement circumstances. The strength of the expectations may also affect whether assimilation or contrast effects are observed".

Attempts by researchers to empirically test the assimilationcontrast model have met with varied results. For instance, Anderson and Olson and Dover found some evidence to support the assimilation theory approach. In debating both of these studies, Oliver argues that Anderson and Olson and Dover findings cannot be accepted because they only measured expectations and supposed that there were perceptual differences between disconfirmation or satisfaction. This criticism is of some significance because researchers do not actually measure satisfaction or dissatisfaction; instead, researchers usually assumed that it is the perception of disconfirmation that leads to satisfaction or dissatisfaction. In contradiction to the findings supporting the assimilation theory, Cadotte, Woodruff and Jenkins reported negative correlation between expectation and disconfirmation. They therefore resolved that satisfaction is truly an "additive function of the two concepts". Further, Peyton et al., asserts that uncertainty was created by results of studies from the works of Oliver, which found no relationship between expectation and disconfirmation. Moreover, Olshavsky and Miller in "consumer expectations, product performance and perceived product quality" supported the assimilation-contrast theory. However, it has been found that if the discrepancy was too large to be assimilated, then the contrast effect occurs.

\subsection{Negativity Theory}

Similar to the three previous models, negativity theory also has its foundations in the disconfirmation process. This theory developed by Carlsmith and Aronson (1963) suggests that any discrepancy of performance from expectations will disrupt the individual, producing, negative energy ${ }^{\text {ee }}$. Negative theory has its foundations in the disconfirmation process Negative theory states that when expectations are strongly held, consumers will respond negatively to any disconfirmation. "Accordingly dissatisfaction will occur if perceived performance is less than expectations or if perceived performance exceeds expectations. Affective feelings toward a product or service will be inversely related to the magnitude of the discrepancy.

\section{Conceptual Framework}

A conceptual framework can be defined as a set of broad ideas and principles taken from relevant fields enquiring how to structure a subsequent presentation (Reichel and Ramey, 2007). As a research tool, it is intended to assist the researcher develop awareness and understanding of the situation under scrutiny and communicate it. The conceptual framework of this study included independent variables, pricing, service quality, service recovery, brand image and the dependent variable was customer satisfaction. Independent variables are the factors that the researcher thinks will explain the variations while the dependent variable is the variable that the researcher attempts to predict (Orodho and Kombo, 2002)

\subsection{Research Gaps}

The marketing literature is replete with models on the measurement of customer perceptions of service quality (Cronin and Taylor, 2002; Parasuraman et al, 2008; Parasuraman et al. 2005). Studies have also examined the relationship of customer satisfaction and customer loyalty with service quality (Andreassen and Lindestad, 1998; Cronin and Taylor, 2002; Dabholkar et al., 2000). Even in the telecommunication sector research has examined the impact of service quality on customer satisfaction and loyalty (Krepapa et al., 2003; Levesque and McDougall, 1996; McDougall and Levesque, 2000: Ndubisi and Wah. 2005).

With the emergence of sophisticated technologies, studies have also looked at the perceptions of customers regarding the service quality of technology in the telecommunication sector (AlHawari et al., 2005; Curran and Meuter, 2005). However, studies have not focused on value added services and customer service strategies e.g. price, brand image and service recovery strategies especially in the service sector. This study will fill this gap by determining the extent to which value added services such as objects such as SMS and MMS. WAP, GPRS. music, news, games and ring tones as well as customer care services impacts on customer satisfaction in the telecommunication sector in Kenya.

\subsection{Data Analysis and Presentation}

According to Orodho (2003), research design is a chance, outline or plan that is used to generate answer to research problems. It is needed because it facilitates a smooth sailing of the various research operation thereby making research as efficient as possible yielding maximum information with minimum expenditure of effort, time and money (Kothari, 2003).The study adopted a descriptive survey design. This design is ideal because the study aimed at collecting 


\section{International Journal of Science and Research (IJSR) \\ ISSN (Online): 2319-7064 \\ Index Copernicus Value (2013): 6.14 | Impact Factor (2015): 6.391}

information from respondents on their attitudes and opinions in relation to managerial behavior on reward system.

According to Mugenda and Mugenda (2003) descriptive survey is a method which enables the research to summarize and organize data in an effective and meaningful way. Cooper and Schindler (2003) view that descriptive survey method is concerned with finding out who, what, where, when and how much. This is concerned with the how ,the various customer service strategies influence the satisfaction of customers in the telecommunication sector..

Descriptive survey method provides tools for describing collections of observations and reducing the collected information to understandable form.

\subsection{Data Presentation}

Quantitative data was presented through statistical tools such as frequency distribution tables, pie-charts, bar-graphs etc for easy understanding. The researcher then interpreted the research findings from the evidence presented by the data collected. Conclusions were based on the findings. Finally guided by the objectives of the study, the researcher made recommendations. Mugenda and Mugenda (2003) explains that recommendations must be consistent with the purpose of the study and its objectives. Qualitative data was presented descriptively.

\section{Methodology}

The study adopted a descriptive survey design. The target population was made of customers of the telecommunication firms in Nairobi Central Business District. The researcher, using the Nassiuma sample size determination formula, identified a sample of 150 respondents. According to Mugenda and Mugenda (2003), a sample size representing $10 \%$ of the target population is adequate as long as it will have a minimum of 30 elements.

\section{Results and Discussion}

The data collection instrument was a questionnaire which was sent to a sample of 150 respondents. However, only 118 questionnaires were returned adequately filled in. This means that $79 \%$ of the respondents filled in the questionnaires and $21 \%$ did not respond.

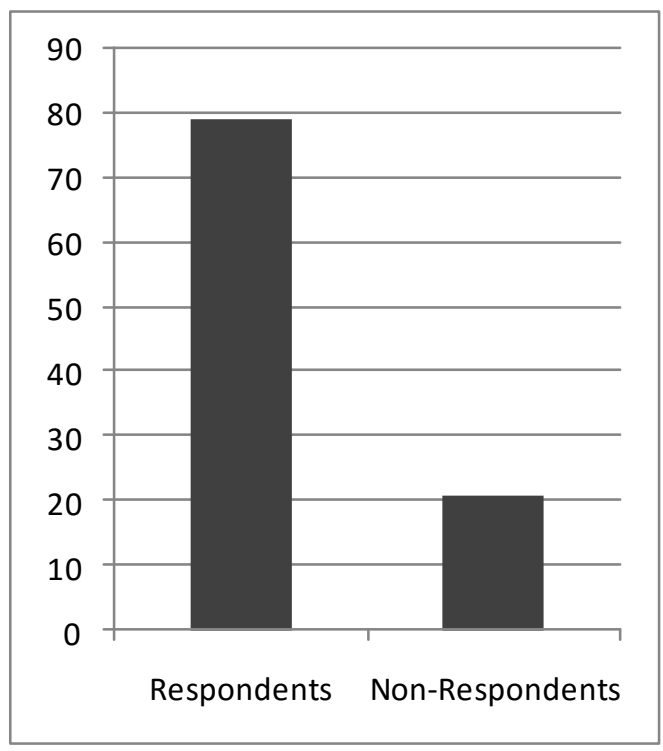

\subsection{Response Rate}

This response rate was considered adequate for reporting as it exceeded the generally accepted threshold of $50 \%$ (Mugenda \& Mugenda 2003).

\subsection{Age of Respondents}

From the research findings that majority of the respondents $39(33 \%)$ were aged 45 years and above, $33(28 \%)$ between 25-35 years, 28 (24\%) were aged $36-45$ years and $18(15 \%)$ were aged below 25 years. This shows that majority of the respondents were above the age of 25 years and therefore mature and well versed with relevant information on the strategies applied by the mobile phone companies. The fact that there were only few respondents in the below 25 years category may be explained by the fact that young people are not actively employed therefore lack money to afford these network services (Anyapong 2012).

\section{Pricing}

Majority of the respondents strongly agreed that pricing strategies have a significant effect on customer satisfaction in the telecommunication sector with both correlation and multiple regression analysis results supporting the findings. In addition, most of the respondents agreed that prices they conceived to be unfair, unjustified and questionable caused dissatisfaction among them. These findings corroborates with previous studies such as Srikanjanarak and Ramayah (2009); meaning that when the customer perceive the price as being fair, the satisfaction outcome will be positive likewise when they perceive price to be unfair the outcome of satisfaction will be negative.

\section{Service Quality}

The analysis of the research data showed that service quality is a major predictor of customer satisfaction. Furthermore, the service quality dimension was found to have significant positive effect on customer satisfaction and retention. Majority of the respondents strongly agreed that service quality strategies have a significant effect on customer satisfaction in the telecommunication sector with both 


\section{International Journal of Science and Research (IJSR) \\ ISSN (Online): 2319-7064 \\ Index Copernicus Value (2013): 6.14 | Impact Factor (2015): 6.391}

correlation and multiple regression analysis results supporting the findings. Most of the respondents agreed that uninterrupted services, wide area network coverage and individual attention were key to ensuring that they were satisfied with the services offered by the telecommunication firms. These findings corroborates with several studies such as Han et al (2008) Bolton (1998); Gustafsson, Johnson, and Rose (2005); Cronin, Brady, and Holt (2000); Seiders et al (2005); Henning-Thurau, Gwinner, and Gremler (2002). This means that when customers ${ }^{\text {ee }}$ expectations are fulfilled in a transaction, the probability of the customer repurchasing is high, as consistent with Wong and Sohal (2003). Therefore satisfied customers display loyalty behavioral outcomes. The more satisfied customers are with the quality of services offered, the more they will repurchase.

\section{Service Recovery}

Data analysed from the responses in the questionnaires indicated that service recovery strategies have significant effects on customer satisfaction with both correlation and multiple regression analysis results supporting the findings. The findings revealed a significant positive relationship between the relationship between service recovery based on firm 's understanding of customer complaints and customer satisfaction.

Boshoff (2007) showed that once customers receive an apology or once they receive an apology and a free gift or likewise, their recovery satisfaction and behavioral intention improve significantly. As a result, many service organizations offer various combinations of refunds, credit, discounts, and apologies to make peace with dis-satisfied customers. The speed with which service failures are corrected or complaints are handled is one of the major determinants of customer perceptions of procedural justice (Blodgett et al. 2007; Tax et al. 2008). Offering a causal explanation for a service failure contributes to understanding of the customeres complaint. The study also revealed that there is a significant positive relationship between service recovery based on firm's fair treatment of customer complaints and customer satisfaction.

Essentially, service firms believe that customers who are recovered are the ones that spread the value of business to others, leading to new people to business and helping the company grow. The relationship has a merit that a customer who is fairly recovered will use the firms services regularly is likely to spread the word to others. Furthermore, findings showed a positive correlation between service recovery and customer satisfaction.

\section{Brand Image}

The analysis of the research data showed that brand image is a major predictor of customer satisfaction. Furthermore, the brand image dimension was found to have significant positive effect on customer satisfaction and retention. Most respondents agreed that their view that the service provider was socially responsible and a leader in the telecommunications sector contributed a lot to their satisfaction. This is further supported by the fact that data analyzed from the responses in the questionnaires indicated that brand image strategies have significant effects on customer satisfaction with both correlation and multiple regression analysis results supporting the findings.

Brand image has a significant impact on customer satisfaction especially across the telecommunication industries. Chitty et al. (2007) also empirically proved the dominant role of brand image in predicting customer satisfaction in the telecommunication industry. Moreover, the congruence between the brand image and customerse self-image would enhance customer satisfaction and customers $^{e e}$ preference for the brand. Customer loyalty could be recognized as the extension of customer satisfaction. Foxall and Goldsmith (2004) proposed that the perception of the customer about the characteristics of the product and service is influenced by the perceptions about the brand and branding. The vital aim of the brand and product management is to build strong brand image which in turn generate the huge short term and long term profit (Aaker, 2001). So there is a positive impact of brand image on the customer satisfaction and commitment towards the offerings of the market.

\section{Conclusion}

From the findings of the study, it can be concluded that the telecommunication companies in Kenya have put in place strategies of customer service to enhance customer retention. It is imperative that the telecommunication industry executives are improving performance on each construct that leads to customer retention to improve their competitiveness in the industry.

The study highlights a number of areas that have been shown to have significant impact for consumers ${ }^{\text {ee }}$ satisfaction. It is important for manager to identify the needs of the customers and develop appropriate service quality, pricing, service recovery and brand image strategies to meet such needs. This is so because this study has shown that there is a strong relationship between customers ${ }^{\text {ee }}$ perceived service quality and price fairness level and customer satisfaction. That is if customers" perceived service quality and price fairness level is high, satisfaction will also be high. The importance of equally developing brand image and service recovery strategies cannot also be ignored. The study has shown that customers $^{\text {ee }}$ satisfaction and consequently retention is achieved only when the customers believe that customers services offered are effective and of high quality.

\section{Recommendations}

The main objective of this study was to investigate the effects of customer service strategies on customer satisfaction of firms in the telecommunication sector in Kenya.

Recommendations that follow are aimed at improving areas of concern in order to enhance customer satisfaction.

The study makes the following recommendations guided by the objectives of the study. 


\subsection{Recommendations on Pricing}

The findings imply that mobile network companies should not only avoid exploiting their customers but should also anticipate consumers ${ }^{\text {ee }}$ potential feelings of being exploited. Being sensitive to the buyers ${ }^{\text {ee }}$ psychological state and assuring buyers of fair treatment will enhance perceptions of price fairness without changing the price offer. Taken together, managers of these companies need to put measures in place to swiftly tackle connectivity problems and to deliver quality, reliable services at reasonable prices which are especially fair to consumers considering the level of services that are been delivered.

\subsection{Recommendations on Service Quality}

There is need for the management of telecom firms to intermittently train their workers on relationship marketing skills. Such training would build a customer-oriented climate in which contact staff can deliver service efficiently and effectively, acknowledging that acquiring and retaining customers is the very essence of marketing. Consequently, customer relations behaviour can serve as the criteria for telecom staff performance evaluations and promotions.

\subsection{Recommendations on Service Recovery}

Management of telecommunication firms should undertake various research works to find out the various needs of its subscribers as well as its potential subscribers. Communication of forthcoming interruptions due to upgrading of systems or breakdown of systems via email, Telephone, SMS, radio, television, newspapers or even on the telecommunication firms ${ }^{\text {ee }}$ website as a means of creating "a better service".

\subsection{Recommendations on Brand Image}

Telecommunication managers must make a concerted effort to develop a distinct brand image or brand identity that resonates with customers but also clearly distinguishes that brand from its competitors. Identity distinctiveness can attract customers to develop identification with the brand. In developing marketing programs and campaigns that foster strong customer satisfaction, the managers must apply strategies that will strengthen brand loyalty. Creating a clear, unique identity that targets customer segments desire allows a sustainable differentiation of the offering and helps to enhance customers' identification with the brand (Baumgarth and Schmidt, 2010).

\subsection{Recommendations for Further Research}

As it has been pointed out, the survey sample is rather skewed towards a particular mobile telephony user profile. More easily generalizable conclusions could be drawn by aiming at a sample that would better represent Kenyan mobile telephone users. This study was conducted in Nairobies central business district. A future study similar to this should be carried out in other areas and counties and findings be compared to help telecommunication managers and other managers in the service industry find concrete solutions to poor customer satisfaction in Kenya.

\section{References}

[1] Agarwal, S., Erramill, M. and Dev, C. (2003), "Market orientation and performance in service firms: role of innovation", Journal of Services Marketing, Vol. 17 No 1, pp. 68-82.

[2] Anderson, E.W. and Sullivan, M. (1993), "The antecedences and consequences of customer satisfaction for firms", Marketing Science, Vol. 12 No. 2, pp. 125-43.

[3] Ary, D., Jacobs, L., and Razavieh, A. (2002), Introduction to Research in Education, 6th Ed., Belmont, CA: Wadsworth/Thomson Learning.

[4] Balmer, J.M.T. (2009), "Corporate marketing: apocalypse, advent and epiphany", Management Decision, Vol. 47 No. 4, pp. 544-572.

[5] Baron, R. and Kenny, D.A. (1986), "The moderatormediator distinction in social psychological research: conceptual, strategic, and statistical considerations", Journal of Personality \& Social Psychology, Vol. 51 No. 6 , pp. 1173-82.

[6] Bennett, R. (2005), “Competitive environment, market orientation, and the use of relational approaches to the marketing of charity beneficiary services", Journal of Services Marketing, Vol. 19 No.7, pp. 453-469.

[7] Caruana, A. (2002), "Service loyalty: the effects of service quality and the mediating role of customer satisfaction", European Journal of Marketing, Vol. 36 Nos 7/8, pp. 811-28.

[8] Chou, C.M and Chang, S.C. (2006), "Factors affecting China Mobile Customer satisfaction", available at: http:/www.decisionsciences.org/Proceedings/DSI2008/ docs/17-9824.pdf (Accessed: December 15th 2015).

[9] Churchill, G.A. and Surprenant, C.F. (1982), “An investigation into the determinants of customer satisfaction", Journal of Marketing Research, Vol. 19, November, pp. 491-504.

[10] Clarke, T. (1998), "The stakeholder corporation: a business philosophy for the information age", Long Range Planning, Vol. 31 No. 2, pp. 182-94.

[11]Dwyer, F. Robert, Paul H. Schurr, and Sejo Oh (1987), "Developing Buyer-Seller Relationships," Journal of Marketing, 51 (April), pp 11-27.

[12] Eisenhardt, K.M. (1989), "Building theories from case study research", Academy of Management Review, Vol. 14 No. 4, pp. 532-50.

[13]Ellis, P.D. (2005), "Market orientation and marketing practice in a developing economy," European Journal of Marketing, Vol. 39 No. 5/6, pp. 629-645.

[14] Field, A. (2005), Discovering Statistics, Using SPSS for Windows, Sage Publications, London.

[15]Fink, C., Aaditya, M. and Randeep, R. (2002), 'Liberalizing Basic Telecommunications: Evidence from Developing Countries", World Bank, Working Paper.

[16] Garengo, P., Biazzo, S., and Bititci, U. S. (2005), "Performance measurement systems in SMEs: a review for a research agenda", International Journal of Management Reviews, Vol. 7 No. 1, pp. 25-47.

[17] Gronroos, C. (1988), "Service quality: the six criteria of good perceived service quality", Review of Business, Vol. 9, pp. 10-13. 
[18] Haggarty, L., Shirley, M.M. and Wallsten, S. (2002), "Telecommunications Reforms in Kenya", World Bank, Working Paper.

[19]Kotler, P. (2003), Marketing Management, PrenticeHall. Englewood Cliffs, NJ.

[20] LaBarbera, P.A. and Mazursky, D. (1983), “A longitudinal assessment of consumer satisfaction and dissatisfaction: the dynamic aspect of the cognitive process", Journal of Marketing Research, Vol. 29, November, pp. 393-404.

[21] Mugenda, O., \& Mugenda. A. (2003). Research Methods: Qualitative and Quantitative Approaches. Nairobi. Africa Center for Technology Studies.

[22] Miller, J.L., Craighead, C.W. and Karwan, K.R. (2000), "Service recovery: a framework and empirical investigation", Journal of Operations Management, Vol. 18 No. 4, pp. 387-400.

[23] Nachmias, D., \&Nachmias, F.C. (2008).Social Statistics for a diverse society with SPSS student version 16 (5th Ed.). Milwaukee: Sage Publications.

[24] Ordho, A. (2003). ,Essentials of educational and social sciences research methods ${ }^{\mathrm{ee}}$. Nairobi: Masola Publishers.

[25] Parasuraman, A., Berry, L.L. and Zeithami, V.A. (1988), „SERVQUAL: A multiple-item scale measuring consumer perceptions of service quality", Journal of Retailing, Vol. 64 No. 1, pp. 23-40, 52-53.

[26] Rust, R., Katherine L. and Zeithaml, V.L. (2004), "Return on marketing: Using customer equity to focus marketing strategy", Journal of Marketing, Vol. 68, January, pp.109-124.

[27] Sivadas, E. and Baker-Prewitt, J.L. (2000), "An examination of the relationship between service quality, customer satisfaction, and store loyalty", International Journal of Retail \& Distribution Management, Vol. 28 No. 2, pp. 73-82.

[28] Tsang, J.H.Y. and Antony, J. (2001), "Total quality management in UK service organizations: some key findings from a survey”, Managing Service Quality, Vol. 11 No. 2, pp. $132-141$.

[29] Voss, G.B., Parasuraman, A. and Grewal, D. (1998), "The role of price, performance and expectations in determining satisfaction in service exchanges", Journal of Marketing, Vol. 62, October, pp. 46-61.

[30] Walker, O.C., Boyd, H.W. and Larreche, J.C. (1992), Marketing Strategy: Planning and Implementation, Irwin, Homewood, Illinois.

[31] Westbrook, R. A. (1980), "Intrapersonal Affective Influences on Consumer Satisfaction with Products", Journal of Consumer Research, Vol. 7, pp. 49-54.

[32] Wirtz, J. (2003), "Halo in customer satisfaction measures", International Journal of Service Sector Management, Vol. 14 No. 1, pp. 96-119.

[33] Yin, R. K., (1994), Case Study Research - Design and Methods, 2nd Edition, Thousand Oaks, CA, Sage Publications. Yin, R.K. (2003), Case Study Research: Design and Methods, 3rd Edition, Sage Publications, Thousand Oaks, CA.

[34]Zeithaml, V.A., Berry, L.L. and Parasuraman, A. (1996), "The behavioural consequences of service quality", Journal of Marketing, Vol. 60 No. 2, pp. 31-46. 